\title{
Cinnamon Stick Aspiration in a Patient with Asthma: A Case Report
}

\section{Astım Tanılı Hastada Tarçın Çubuğu Aspirasyonu: Olgu Sunumu}

Sefa Semih Atal', Omer Ayten', Cengiz Özdemir², Tayfun Caliskan', Bengü Şaylan', Oguzhan Okutan', Zafer Kartaloglu'

\section{Abstract}

Foreign body aspiration into the tracheobronchial system, which is more common in children than adults, can have serious consequences, leading even to mortality and morbidity, and may be diagnosed only after a delay. A foreign body was detected during a flexible bronchoscopy due to stenosis in the left main bronchus in the chest computed tomography of a 59-year-old female patient being followed up for asthma. A cinnamon stick identified in the left main bronchus was removed with rigid bronchoscopy, revealing the asthma to be a misdiagnosis.

Key words: Tracheobronchial system, foreign body aspiration, cinnamon stick, asthma, rigid bronchoscopy.

\section{Özet}

Trakeobronşiyal sisteme yabancı cisim aspirasyonu, çocuklarda erişkinlere göre daha sık görülen, ciddi sonuçlara ve hatta mortalite ve morbiditeye neden olabilen, tanıda gecikme yaşanılan bir durumdur. Astım nedeni ile takip edilen 59 yaşındaki kadın hastanın akciğer bilgisayarlı tomografisinde sol ana bronşta daralma olması nedeni ile yapılan fleksible bronkoskopide yabancı cisim saptanmıştır. Hastaya yanlışlıkla astım tanısı konmuştu.

Anahtar Sözcükler: Trakeobronşiyal sistem, yabancı cisim aspirasyonu, tarçın çubuğu, astım, rijid bronkoskopi.

\footnotetext{
'Department of Pulmonology, Sultan 2. Abdulhamid Han Training and Research Hospital, Health Sciences University, İstanbul, Turkey

2Department of Pulmonology, Yedikule Chest Diseases and Thoracic Surgery Training and Research Hospital, Health Sciences University, İstanbul, Turkey

'Sağlık Bilimleri Üniversitesi, Sultan 2. Abdülhamid Han Eğitim Ve Araştırma Hastanesi, Göğüs Hastalıkları Kliniği, İstanbul

${ }^{2}$ Sağlık Bilimleri Üniversitesi, Yedikule Göğüs Hastalıkları Ve Göğüs Cerrahisi Eğitim Ve Araştırma Hastanesi, Göğüs Hastalıkları Kliniği, İstanbul
}

Submitted (Başvuru tarihi): 05.05.2021 Accepted (Kabul tarihi): 20.05.2021

Correspondence (iletişim): Sefa Semih Atal, Department of Pulmonology, Sultan 2. Abdulhamid Han Training and Research Hospital, Health Sciences University, İstanbul, Turkey 
Foreign body aspiration into the tracheobronchial system is a life-threatening emergency, and early removal and detection are very important if acute and chronic complications are to be avoided. The condition is more common in children, and is a major cause of sudden upper respiratory tract obstruction $(1,2)$. Foreign body aspiration is a significant health problem that is frequently encountered in clinical practice. It can lead to serious consequences, requiring urgent interventions in some cases, and rapid clinical recovery is observed once the foreign body is removed (2). The removal of the foreign body following early diagnosis ensures fewer complications will be encountered, while delays in diagnosis and intervention may lead to serious morbidity and even mortality, and may have clinical and radiological consequences such as recurrent pneumonia, lung abscess and bronchiectasis (3). Foreign body aspiration most commonly involves the right main bronchus $(71.5 \%)$ in adults, and was located in the left main bronchus in $22.8 \%$ and the trachea in $5.7 \%$ of the cases in the review article by $\mathrm{Ra}-$ mos et al. (4). There is a more equal distribution between the two systems in children, but foreign bodies are more common in the intermediate bronchi $(27 \%)$ and right lower lobe (33\%). The aspirated objects are affected by the geography, sociodemographic characteristics, eating habits and other cultural characteristics of the country in question, and can be quite diverse, ranging from edible organic materials, such as hazelnuts and peanuts, to inorganic materials such as toy pieces, earrings and pins $(5,6)$. More rarely, objects such as garlic, cinnamon sticks, razor blades and voice prostheses have also been reported (7-9).

\section{CASE}

A 59-year-old female patient was admitted to the pulmonology department with complaints of shortness of breath, cough, fever and weakness. A computed tomography (CT) of the thorax revealed cavitary images, the largest of which was $18 \mathrm{~mm}$ thick in the lateral segment of the left upper lobe and narrowing in the left main bronchus (Figure $1 \mathrm{a}$ and $\mathrm{b}$ ). The patient had a diagnosis of diabetes mellitus, essential hypertension and asthma, the asthma diagnosis being made 9 years earlier. A previous pulmonary function test (PFT) had shown no obstruction and reversibility was positive. The patient was using inhaled corticosteroid and a long-acting beta-antagonist combination, long-acting muscarinic antagonist, a combination of short-acting beta-antagonists and muscarinic antagonists in nebulized form, and oral corticosteroids for asth- ma treatment. She stated that although she had used her medicines properly and regularly, she had experienced frequent hospital admissions and several hospitalizations due to pneumonia within the 9-year period. She did not smoke and had no known allergies. While in our care, a PFT was repeated and reversibility was observed to be negative. The PFT results were; FVC: 1.49 lit (61\%), FEV1: 1.23 lit (60\%) and FEVI/FVC: 83 ; and the postbronchodilator results were FVC: 1.76 lit (72\%), FEV1: 1.29 lit (63\%) and FEV1 FVC: 74 . The patient was thus found to have been misdiagnosed with asthma. She was also using gliclazide, metformin and valsartan for hypertension, and had no history of tuberculosis or contact with patients with tuberculosis.

The laboratory parameters were reported as glucose: 279 $\mathrm{mg} / \mathrm{dL}$, urea (serum): $18 \mathrm{mg} / \mathrm{dL}$, Lactic Dehydrogenase: $162 \mathrm{U} / \mathrm{L}$, creatinine: $0.55 \mathrm{mg} / \mathrm{dL}$, sodium: $137 \mathrm{mmol} / \mathrm{L}$, C-reactive protein: $131.29 \mathrm{mg} / \mathrm{L}$, sedimentation: 120 $\mathrm{mm} /$ hour, ferritin: $75.68 \mathrm{ng} / \mathrm{mL}, \mathrm{N}$-terminal Pro Brain Natriuretic Peptide: $1958 \mathrm{ng} / \mathrm{L}$, White blood cell count: $13.61 \times 10^{3} / \mathrm{mm}^{3}$, hemoglobin: $7.8 \mathrm{~g} / \mathrm{dL}$, hematocrit: $25.7 \%$, platelet count: $450 \times 10^{3} / \mathrm{mm}^{3}$, procalcitonin: $0.151 \mathrm{ng} / \mathrm{mL}$ and high sensitive troponin: $17.78 \mathrm{ng} / \mathrm{L}$ in the blood taken from the patient.

An internal medicine consultation was requested due to anemia. Since the patient's iron, folic acid and vitamin B12 levels were low, hemoglobin electrophoresis, fecal occult blood test, gastroscopy and colonoscopy were recommended.

The culture of the sputum sample taken from the patient was compatible with the upper respiratory tract flora. Sputum acid-resistant bacilli (ARB) direct examination and Mycobacterium tuberculosis sputum polymerase chain reaction (PCR) were negative. A $2019 \mathrm{nCoV}$ Real-Time PCR was negative. Antibiotherapy was initiated with ceftriaxone $1000 \mathrm{mg} \mathrm{2 \times 1} \mathrm{IV} \mathrm{and} \mathrm{clarithromycin} 500 \mathrm{mg}$ $2 \times 1$ pod.

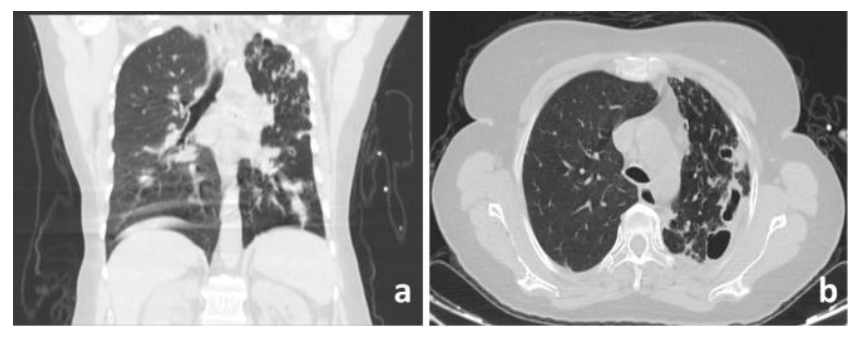

Figure 1: Stenosis of the left main bronchus on computed tomography of the lung (a) and thick-walled consolidated areas and an image of cavitation in the left hemithorax (b) 


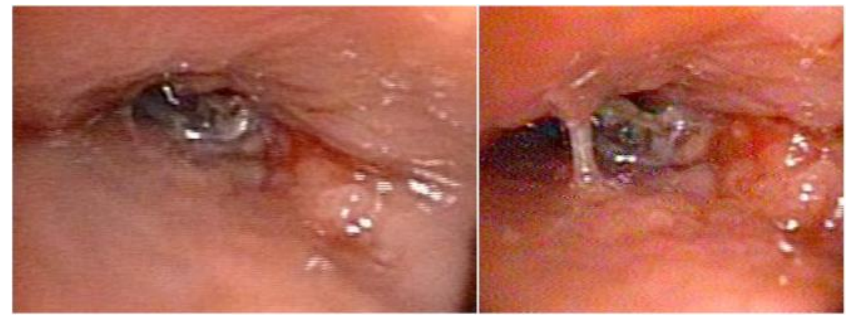

Figure 2: Foreign body surrounded by granulation tissue in the proximal left main bronchus

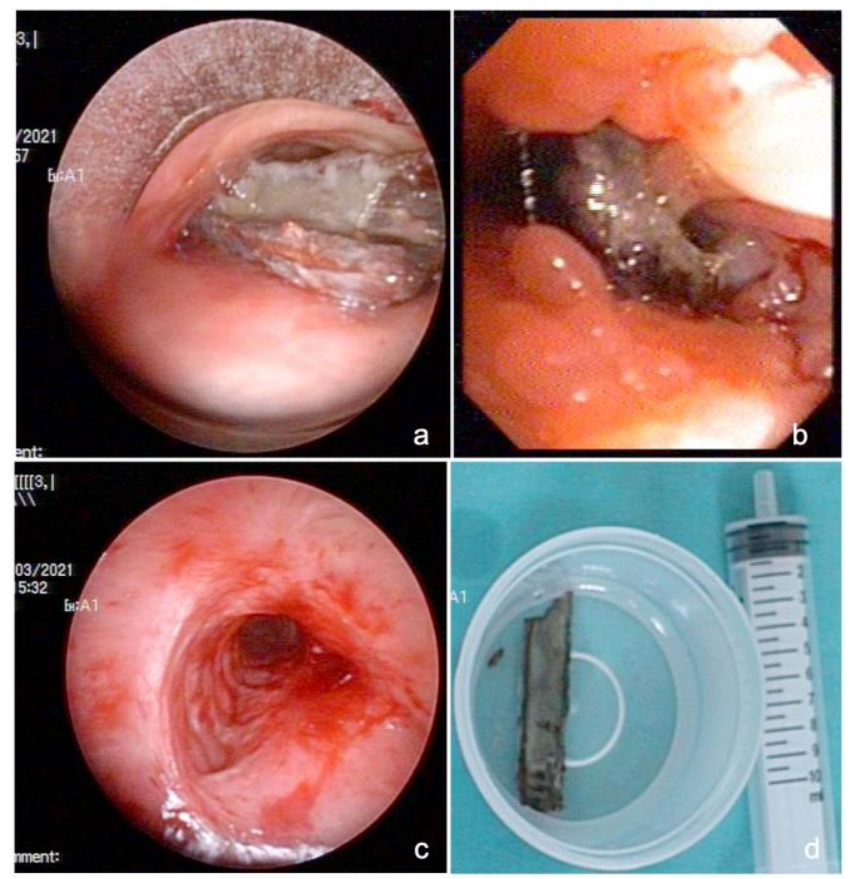

Figure 3: Foreign body surrounded by granulation tissue observed in the proximal left main bronchus with rigid bronchoscopy $(a, b)$; view of the left main bronchus after the removal of the foreign body (c); an approximately $10 \mathrm{~cm}$-long cinnamon stick (d)

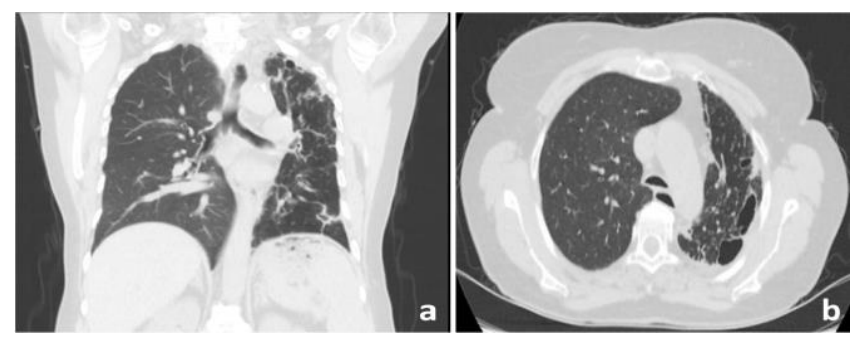

Figure 4: Reticulonodular infiltration foci and linear fibroatelectatic band formations were observed in the subpleural areas in all left lobes. When evaluated comparatively with a previous chest computed tomography, it was observed that the size of the cavitary lesion decreased. Furthermore, the large consolidated area with round characteristics in the left lung lower lobe posterobasal was largely regressed in the current examination. Mild peribronchial thickness increases can be noted in the left upper lobe and lower lobe bronchi

A flexible bronchoscopy (FOB) was planned for the patient, whose lung computed tomography showed stenosis in the left main bronchus. The left main bronchus entrance was found to be narrowed by $80 \%$ in bronchoscopy, and the purulent secretions in the proximal part were aspirated. A foreign body surrounded by granulation tissue was noted in the proximal of the left main bronchus (Figure 2), and a fiberoptic bronchoscope was unable to access distal to the left main bronchus, and was lavaged. Following the bronchoscopy, when the patient was questioned about possible foreign body aspiration, it was learned that the patient had accidentally swallowed a cinnamon stick that she had added to her tea 9 years earlier, after which he applied to the emergency department with intense cough and shortness of breath but no cyanosis, and was discharged after undergoing bronchodilator treatment. It was decided to perform rigid bronchoscopy to remove the foreign body, which was surrounded by granulation tissue in the proximal left main bronchus. The foreign body was removed as a whole from the granulation tissue with rigid bronchoscopy (Figure 3). The removed foreign body was a cinnamon stick, approximately $10 \mathrm{~cm}$ in length, which had preserved its integrity. There were no complications during or after the procedure.

A growth of Klebsiella oxytoca was identified in the nonspecific lavage culture, while other cultures and tests were negative, and there were no findings in favor of malignancy observed in a cytological examination. In accordance with the culture antibiogram, amoxicillin /clavulanic acid $1000 \mathrm{mg} \mathrm{2x1}$ pod was prescribed to the patient, and after regression in the infection parameters and improvement in the patient's clinical course, she was discharged from the hospital. A control thorax computed tomography and $F O B$ was planned for the first month after the procedure, and the left main bronchus was observed to be completely open, and the size of the cavitary lesions associated with the bronchial structures in the subpleural areas in the left upper lobe and lower lobe basal-posterior segment had decreased in the control chest computed tomography performed 1 month after the rigid bronchoscopy (Figure 4). Flexible bronchoscopy revealed the left main bronchus to be open.

\section{DISCUSSION}

Early admission to the hospital is important for a patient with a history of foreign body aspiration, as this will improve the success rate of the removal procedures (2). At the same time, the rate of complications that may develop with early diagnosis, and the possibility of false diagnoses in the future, will also decrease (2). Our case was being followed for asthma for many years, and it was observed that pneumonic infiltrates progressed to cavitary lesions in the lung parenchyma over time. The patient's 
quality of life decreased and there were frequent hospital admissions and hospitalizations, clarifying the importance of early diagnosis and intervention.

Although foreign body aspirations are more frequently seen in childhood, they can occur in all age groups. They are most common in children aged $0-3$ years and later in those over 75 years of age (2). The most common foreign body aspiration materials in children are hazelnuts, peanuts, sunflower seeds, chickpeas, pencil caps and watermelon seeds (10), while the most common foreign body aspiration materials in adult individuals in our country are pins (11). Among the organic objects, it is mostly nuts that are aspirated (2). In cases of aspiration of large-sized inorganic objects, such as dental prostheses, money, bone fragments and beads, a complete occlusion of the tracheobronchial system may develop that may result in death $(9,12)$. Foreign body aspirations in adults have been found to be most common (71.5\%) in the right main bronchus (4), while in our case, a foreign body that was located in the proximal left main bronchus that caused an almost $80 \%$ obstruction was detected. There have been a number of case series published involving interesting objects, and the aspiration and removal of a cinnamon stick was reported in only one case in a review of studies of 25,998 bronchoscopies performed for foreign body aspiration in adults (9). Our case is thus an extremely rare and interesting example of foreign body aspiration.

The most common clinical finding with foreign body aspirations is the cough crisis that occurs due to the foreign body irritating the tracheobronchial system. When the patient's anamnesis is taken, it is commonly stated that sudden coughing attacks start immediately after the object is aspirated as a result of such activities as laughing, sneezing and speaking when there is a foreign body in the mouth (2). Aside from this, clinical findings such as respiratory distress, tachypnea, wheezing, stridor, hemoptysis, sputum production, vomiting and fever can also be seen in patients $(12,13)$. Stridor is seen especially when the aspirated object does not completely occlude the main bronchus or trachea, although the patient may rarely be asymptomatic. Although similar clinical findings are observed in children, most parents describe a sudden onset of severe cough and bruising (2). Our patient presented with complaints of long-term shortness of breath and cough, and she stated that her complaints had continued, despite bronchodilator treatment.

In tracheobronchial foreign body aspirations, the patient's anamnesis - taken from the parents if the patient is a child - is often sufficient for diagnosis, and so should be questioned to the smallest detail. Radiological examinations and bronchoscopic evaluations are also required for diagnosis in patients with suspected foreign body aspiration with anamnesis. For this, if the patient's vitals are stable and the general condition is good, the first thing that should be requested is an anterior-posterior and lateral chest radiography, followed by a thorax CT. Radiopaque substances can be easily detected during imaging studies (needles, money, other metal objects, etc.). If the object is not radiopaque, a diagnosis can be made based on secondary changes that may occur as a result of the aspiration. For example, if there is a foreign body completely obstructing a lobe or segment bronchus, signs of atelectasis or obstructive pneumonia may be detected in the distal of the obstruction, such findings being frequently encountered in patients who present a few days or weeks after foreign body aspiration. In patients with suspected foreign body aspiration, normal radiological images do not exclude aspiration, and therefore, bronchoscopy should be evaluated. Rigid bronchoscopy should be performed quickly in case of deterioration in the general condition of the patient, desaturation in room air or under oxygen support, cyanosis or upon an increase in respiratory distress. If an early diagnosis cannot be made, over time, secondary conditions may develop secondary to chronic inflammatory processes, such as obstructive pneumonia, lung abscess, bronchiectasis and cavitary lesions due to infections (2). Foreign bodies that are not removed for a long time become covered with granulation tissue, and can resemble an endobronchial mass with the potential for misdiagnosis as bronchial carcinoma (14). In our case, who could not be diagnosed and was treated for asthma for many years, pneumonia and cavitary lesions due to foreign body aspiration were observed, and the body had in time become covered with granulation tissue as a result of the endobronchial interventional processes.

Bronchoscopic procedures have an important place in both the diagnosis and removal of tracheobronchial foreign bodies. Rigid bronchoscopy is the most common approach to the removal of aspirated foreign bodies from the tracheobronchial system, which, being performed under general anesthesia, has disadvantages when compared to fiberoptic bronchoscopy. On the other hand, a detailed evaluation of the distal airways can be made by sending a FOB through the rigid bronchoscope (2). In our case, a FOB was first performed, and the foreign body was found to be surrounded by granulation tissue. After being evaluated to be organized, it was decided to 
remove the foreign body through rigid bronchoscopy. Under general anesthesia, the cinnamon stick that our patient had aspirated into her tracheobronchial system nearly 9 years earlier, was successfully removed in one piece, and without complications either during or after the procedure.

Tracheobronchial foreign body aspiration is a significant health problem in which rapid clinical recovery can be observed with early diagnosis and treatment. A detailed anamnesis is often diagnostic. After an anamnesis is taken and a physical examination has been performed, the patient with a suspected foreign body should be evaluated quickly through a radiological examination and bronchoscopic procedures. Although symptoms secondary to foreign body aspiration are usually seen acutely, it should be kept in mind that respiratory system symptoms may develop in cases of foreign bodies aspirated a long time ago, as in the patient in the present study.

\section{CONFLICTS OF INTEREST}

None declared.

\section{AUTHOR CONTRIBUTIONS}

Concept - S.S.A., Ö.A., C.Ö., T.Ç., B.Ş., O.O., Z.K.; Planning and Design - S.S.A., Ö.A., C.Ö., T.Ç., B.S.., O.O., Z.K.; Supervision - S.S.A., Ö.A., C.Ö., T.Ç., B.Ş., O.O., Z.K.; Funding - S.S.A., Ö.A., C.Ö., T.Ç.; Materials - S.S.A., Ö.A., C.Ö., T.Ç.; Data Collection and/or Processing - S.S.A., T.Ç.; Analysis and/or Interpretation T.Ç., B.Ş., O.O., Z.K.; Literature Review - S.S.A., T.Ç.; Writing - S.S.A., T.Ç.; Critical Review - S.S.A., T.Ç., B.Ş., O.O., Z.K.

\section{YAZAR KATKILARI}

Fikir - S.S.A., Ö.A., C.Ö., T.Ç., B.Ş., O.O., Z.K.; Tasarım ve Dizayn - S.S.A., Ö.A., C.Ö., T.Ç., B.S.., O.O., Z.K.; Denetleme - S.S.A., Ö.A., C.Ö., T.Ç., B.Ş., O.O., Z.K.; Kaynaklar - S.S.A., Ö.A., C.Ö., T.Ç.; Malzemeler S.S.A., Ö.A., C.Ö., T.Ç.; Veri Toplama ve/veya İşleme S.S.A., T.Ç.; Analiz ve/veya Yorum - T.Ç., B.S.., O.O., Z.K.; Literatür Taraması - S.S.A., T.Ç.; Yazıyı Yazan S.S.A., T.Ç.; Eleştirel İnceleme - S.S.A., T.Ç., B.Ş., O.O., Z.K.

\section{REFERENCES}

1. Salih AM, Alfaki M, Alam-Elhuda DM. Airway foreign bodies: A critical review for a common pediatric emergency. World J Emerg Med 2016; 7:5-12. [CrossRef]
2. Yazıcıoğlu A, Karaoğlanoğlu N. Trakeobronşiyal yabancı cisim aspirasyonları In: Metintaş M, Selçuk ZT, Yılmaz A editörler. Girişimsel Pulmonoloji. 1. baskı. Ankara: Rotatıp Kitabevi ; 2014:229-33.

3. Sirmali M, Turut H, Kisacik E, Findik G, Kaya S, Tastepe I. The relationship between time of admittance and complications in paediatric tracheobronchial foreign body aspiration. Acta Chir Belg 2005; 105:631-4. [CrossRef]

4. Blanco Ramos M, Botana-Rial M, Garcia-Fontan E, Fernandez-Villar A, Gallas Torreira M. Update in the extraction of airway foreign bodies in adults. J Thorac Dis 2016; 8:3452-6. [CrossRef]

5. Büyükyavuz İ. Çocukluk çağında yabacı cisim aspirasyonu. Klinik Pediatri 2003; 2:47-51.

6. Ciftci AO, Bingol-Kologlu M, Senocak ME, Tanyel FC, Buyukpamukcu N. Bronchoscopy for evaluation of foreign body aspiration in children. J Pediatr Surg 2003; 38:1170-6. [CrossRef]

7. Rodrigues AJ, Oliviera EQ, Scordamaglio PR, Gregório MG, Jacomelli M, Figueiredo VR. Flexible bronchoscopy as the first choice method of removing foreign bodies from the airways of adults. J Bras Pneumol 2012; 38:315-20. [CrossRef]

8. Altuntaş B, Aydin Y, Eroğlu A: Complications of tracheobronchial foreign bodies. Turk J Med Sci 2016; 46: 795-800. [CrossRef]

9. Sehgal IS, Dhooria S, Ram B, Singh N, Aggarwal AN, Gupta D, et al. Foreign body inhalation in the adult population: experience of 25,998 bronchoscopies and systematic review of the literature. Respir Care 2015; 60:1438-48. [CrossRef]

10. Çobanoğlu U, Mergan D. Okul çağı çocuklarında kalem kapağı aspirasyonları: eğitmen ve ailelerin dikkat etmesi gereken bir konu. J Clin Anal Med 201 1; 2:21-3.

11. Kaptanoğlu M, Nadir A, Doğan K, Şahin E. The heterodox nature of "Turban Pins" in foreign body aspiration; the central anatolian experience. Int J Pediatr Otorhinolaryngol 2007; 71:553-8. [CrossRef]

12. Karadaş S, Gönüllü $H$, Sayır F, Aydın İ. A rare cause of dyspnea in elderly patient: foreign body aspiration. J Clin Anal Med 2012; 3:466-8. [CrossRef]

13. Kurul iC, Yorgancılar CD, Çelik A, Karakurt Ö, Demircan S. Trakeobronşiyal yabancı cisim aspirasyonları; 25 olgunun analizi. Gazi Tıp Dergisi 2009; 20: 13-6.

14. Aydoğdu K, Fındık G, Hazer S, Kaya S. Foreign body aspiration involved with bronchial carcinoma: two cases. J Clin Anal Med 2015; 6(suppl 2):216-8. [CrossRef] 